\title{
PRAKTIK KEPEMIMPINAN TRANFORMASIONAL DALAM MENINGKATKAN KOMPETENSI KEPRIBADIAN GURU PERSPEKTIF AL-QUR'AN
}

\author{
MUH. MINAN \\ Sekolah Dasar Negeri Kedaung Kaliangke o1
}

abulaisaljawi@gmail.com

\begin{abstract}
ABSTRAK
Penelitian ini bertujuan untuk mengetahui komponen kepemimpinan transformasional yang dipraktikkan oleh kepala sekolah di SDN Kedaung Kaliangke 03 Pagi sebagai sekolah model SPMI yang meliputi idealized influence, inspirational motivation, intelectual stimulation, individualized consideration, dan initiative of culture. Penelitian ini dilakukan dengan pendekatan deskriptif kualitatif dengan jenis penelitian field study research atau studi lapangan dengan tehnik pengumpulan data melalui: 1) interview yang mendalam. 2) Observasi partisipatif. 3) catatan lapangan dan 4) Dokumen. Proses analisis data dilakukan mulai dari pengumpulan data, editing (pemilahan) dan pengecekan keabsahan data,untuk pengecekan keabsahan data peneliti menggunakan metode tringulasi data. Data dianalisis secara kualitatif dengan mengacu model interaktif Miles dan Huberman, yang meliputi pengumpulan data, reduksi, penyajian data, dan menarik kesimpulan atau verifikasi. Subjek penelitian ini adalah kepala sekolah, dewan guru, tenaga kependidikan dan komite sekolah. Hasil penelitian menunjukkan sebagai berikut: (1) Idealized influence yang dimiliki kepala SDN Kedaung Kaliangke 03 Pagi yaitu kepala sekolah melibatkan guru, karyawan, pengawas pembina, dan komite sekolah baik dalam penyusunan visi, misi, tujuan, dan program kegiatan sekolah, selalu mengadakan rapat rutin terkait dengan kendala yang dihadapi dalam program kegiatan sekolah. (2) Inspirational motivation yang dimiliki kepala SDN Kedaung Kaliangke 03 Pagi yaitu kepala sekolah tidak hanya memakai satu gaya kepemimpinan tapi selalu melihat situasi dan kondisi yang dihadapi. Nilai yang ditanamkan oleh kepala sekolah SDN Kedaung Kaliangke 03 Pagi antara lain saling salam, sapa, senyum. Kepala sekolah bergabung dengan guru dan karyawan saat jam istirahat, atau saat tidak ada tugas atau kewajiban yang harus diselesaikan. (3) Intellectual stimulation yang dimiliki kepala SDN Kedaung Kaliangke 03 Pagi yaitu kepala sekolah menanamkan penyelesaian kerja secara cekatan, tepat waktu, dan kepala sekolah juga menghindari menggurui para guru dan karyawan tetapi mengajak untuk saling bekerjasama. (4) Individualized consideration yang dimiliki kepala SDN Kedaung Kaliangke 03 Pagi yaitu kepala sekolah selalu menindaklanjuti kebutuhan guru, karyawan maupun siswa, selalu mengadakan workshop, pelatihan seperti MGMP internal maupun MGMP ekternal, dan studi banding. (5) Initiative of culture yang dimiliki kepala SDN Kedaung Kaliangke 03 Pagi yaitu kepala sekolah berusaha bersikap positif, seperti hal kecil misalnya sholat dhuha disela-sela kesibukannya, memecahkan masalah misalnya dalam kedisiplinan guru dengan cara mengamati dan menanyakan alasan kenapa sering datang terlambat. Kepala sekolah bersikap tegas terkait dengan kewajiban dalam pelaksanaan tugas dan bersikap lembut atau bahkan ngayomi terlepas dari tugas dan tanggungjawabnya sebagai kepala sekolah. Dalam Praktik kepemimpinan transformasional kepala sekolah yang diterapkan pada SDN
\end{abstract}


Kedaung Kaliangke 03 Pagi persepektif Al-Qur'an adalah dengan melakukan internalisasi nilai-nilai karakter, dengan internalisasi nilai-nilai karakter dan menciptakan budaya relegius sekolah sangat berpengaruh positif dalam meningkatkan kompetensi kepribadian guru. Adapun nilai-nilai karakter yang diinternalisasikan adalah sebagai berikut: (1) kepribadian yang mantap dan stabil. (2) Kepribadian yang dewasa. (3) Kepribadian yang disiplin. (4) Kepribadian yang arif. (5) Kepribadian yang berwibawa. (6) Kepribadian yang teladan bagi peserta didik dan (7) Kepribadian berakhlaq mulia. Proses internalisasi melalui: (1) Pembinaan rutin dan pembiasaan. (2) Reward and Punistment. (3)Aturan-aturan sekolah. (4) Persuasive/ajakan. (5) Penciptaan suasana yang islami/religius dengan pendekatan moral knowing, moral feeling dan moral action dengan tahapan transformasi, transaksi dan traninternalisasi. Implikasi terhadap peningkatan kompetensi kepribadian guru yaitu adanya peningkatan: (1) Kepribadian yang mantap dan stabil dengan indikator guru taat pada norma hukum, sosial dan agama, bangga menjadi guru dan bersih aqidahnya. (2) Meningkatnya kepribadian yang dewasa dengan indikator kemandirian, sabar tidak emosi serta memiliki etos kerja. (3) Adanya peningkatan kepribadian yang arif yaitu dengan indikator pola berfikir dan bertindak sesuai dengan norma agama dan budaya setempat. (4) Kepribadian yang berwibawa dengan indikator gaya dan prilaku guru yang terbuka ketika di ajak bicara dan berprilaku sopan serta tidak melakukan hal-hal yang menghilangkan martabat guru. (5) Adanya peningkatan keteladanan dengan indikator guru-guru tidak kasar dan sombong dalam berbicara dan bersikap dan penampilannya rapi, manarik serta terbiasa kerja keras. (6) Meningkatnya kedisiplinan para guru indikatornya dari dokumen absensi sembilan puluh sembilan persen aktif. (7) Kepribadian yang memiliki akhlaq mulia indikatornya tidak adanya guru yang bertindak melanggar norma-norma agama dan hukum, bersikap jujur, ikhlas dan suka menolong.

Kata Kunci: Kkepemimpinan transformasional kepala sekolah, Kompetensi kepribadian Guru

\begin{abstract}
This study aims to determine the transformational leadership component that is practiced by school principals at SDN Kedaung Kaliangke 03 Pagi as an SPMI model school that includes idealized influence, inspirational motivation, intellectual stimulation, individualized consideration, and initiative of culture. This research was conducted with a qualitative descriptive approach to the type of field study research or field study with data collection techniques through: 1) in-depth interviews. 2) Participatory observation. 3) field notes and 4) Documents. The data analysis process is carried out starting from data collection, editing (sorting) and checking the validity of the data, to checking the validity of the data the researcher uses the method of data tringulation. Data were analyzed qualitatively by referring to the interactive model of Miles and Huberman, which included data collection, reduction, data presentation, and drawing conclusions or verification. The subjects of this study were the principal, the board of teachers, the teaching staff and the school committee. The results showed as follows: (1) Idealized influence possessed by the head of SDN Kedaung Kaliangke 03 Pagi, namely the principal involving teachers, employees, supervisors, and school committees in preparing the vision, mission, goals, and program of school activities, always holding meetings routinely associated with obstacles encountered
\end{abstract}


in school activities programs. (2) Inspirational motivation of the headmaster of SDN Kedaung Kaliangke 03 Pagi, namely the principal not only using one style of leadership but always looking at the situations and conditions encountered. Values instilled by the principal of SDN Kedaung Kaliangke 03 Morning include greetings, greetings, smiles. The principal joins teachers and employees during recess, or when there are no assignments or obligations to be completed. (3) Intellectual stimulation owned by the principal of Kedaung Kaliangke 03 Pagi Elementary School namely the principal implements work completion in a swift, timely manner, and the school principal also avoids patronizing teachers and employees but invites to cooperate with each other. (4) Individualized consideration possessed by the head of SDN Kedaung Kaliangke 03 Pagi, namely the principal always following up on the needs of teachers, employees and students, always organizing workshops, training such as internal MGMPs or external MGMPs, and comparative studies. (5) Initiative of culture owned by the head of SDN Kedaung Kaliangke 03 Pagi, namely the principal trying to be positive, such as small things such as praying in the midst of his busy schedule, solving problems such as in teacher discipline by observing and asking reasons why they often come late. The principal is assertive with regard to obligations in carrying out tasks and is gentle or even nurturing regardless of his duties and responsibilities as a school principal. In the principal's transformational leadership practices that are applied to SDN Kedaung Kaliangke 03 Al-Qur'an perspective morning is to internalize character values, with internalization of character values and creating a school religious culture very positively influential in increasing teacher personality competencies. The internalized character values are as follows: (1) a stable and stable personality. (2) A mature personality. (3) A disciplined personality. (4) Wise personality. (5) An authoritative personality. (6) Exemplary personality for students and (7) Noble character. The internalization process through: (1) Routine and habituation. (2) Reward and Punistment. (3) School rules. (4) Persuasive / solicitation. (5) Creation of an Islamic / religious atmosphere with the approach of moral knowing, moral feeling and moral action with stages of transformation, transaction and internalization. Implications for increasing teacher personal competence are an increase in: (1) A steady and stable personality with indicators of teachers obedient to legal, social and religious norms, proud to be a teacher and clean of their aqidah. (2) Increased adult personality with indicators of independence, patience without emotion and work ethic. (3) There is an increase in wise personality, that is with indicators of thinking and acting in accordance with local religious and cultural norms. (4) An authoritative personality with indicators of teacher's style and behavior that is open when spoken to and behaves politely and does not do things that deprive the teacher of dignity. (5) There is an increase in example by the indicators of teachers not being rude and arrogant in speaking and behaving and their appearance is neat, attractive and accustomed to hard work. (6) Increased discipline of the indicator teachers from absenteeism documents ninety-nine percent active. (7) 7) Personality that has noble moral indicators is the absence of teachers who act in violation of religious and legal norms, being honest, sincere and helpful.

Keywords: Principal transformational leadership, Teacher personality competence 


\section{A. PENDAHULUAN}

Menurut kodrat serta iradatnya bahwa manusia dilahirkan untuk menjadi pemimpin. Sejak Adam diciptakan sebagai manusia pertama dan diturunkan ke bumi, manusia ditugasi sebagai Khalifah fil ardhi. Sebagaimana termaktub dalam Al-Quran Surat $\mathrm{A} \frac{1}{8}$-Baqarah ayat 30 yang berbunyi:

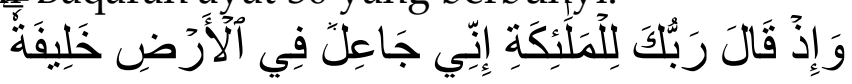

Artinya: 'Ingatlah ketika Tuhanmu berfirman kepada Malaikat'; 'Sesungguhnya Aku akan mengangkat Adam menjadi Khalifah di muka Bumi'. (Q.S. Al-Baqarah [2]: 30) ${ }^{1}$

Allah Ta'ala memberitahukan ihwal pemberian karunia kepada Bani Adam dan penghormatan kepada mereka dengan membicarakan mereka di alMala'ul A'la, sebelum mereka diadakan², Maka Allah berfirman, "Dan ingatlah ketika Tuhanmu berfirman kepada para malaikat." Maksudnya, hai Muhammad, ceritakanlah hal itu kepada kaummu. "Sesungguhnya Aku hendak menjadikan khalifah di bumi." Yakni, suatu kaum yang akan menggantikan satu sama lain, kurun demi kurun, dan generasi demi generasi, sebagaimana Allah Ta'ala berfirman;

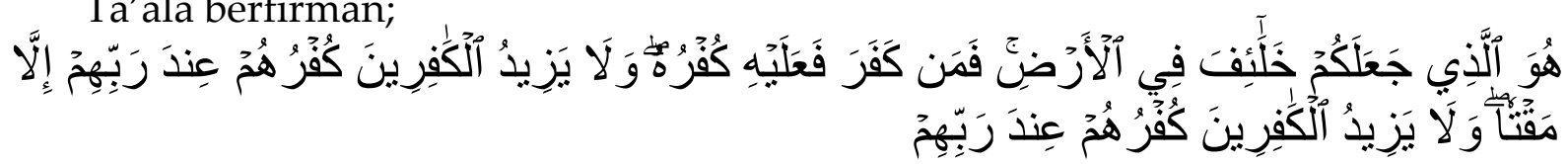

"Dialah yang menjadikanmu sebagai khalifah-khalifah di bumi, Barangsiapa yang kafir, maka (akibat) kekafirannya menimpa dirinya sendiri. Dan kekafiran orang-orang yang kafir itu tidak lain hanyalah akan menambah kemurkaan pada sisi Tuhannya dan kekafiran orang-orang yang kafir itu tidak lain hanyalah akan menambah kerugian mereka belaka." (Q.S. al-Faathir: 39).

Menurut Bachtiar Surin yang dikutip oleh Maman Ukas bahwa "Perkataan Khalifah berarti penghubung atau pemimpin yang diserahi untuk menyampaikan atau memimpin sesuatu". Dari uraian tersebut jelaslah bahwa manusia telah dikaruniai sifat dan sekaligus tugas sebagai seorang pemimpin.Pada masa sekarang ini setiap individu sadar akan pentingnya ilmu sebagai petunjuk/alat/panduan untuk memimpin umat manusia yang semakin besar jumlahnya serta kompleks persoalannya. Atas dasar kesadaran itulah dan relevan dengan upaya proses pembelajaran yang mewajibkan kepada setiap umat manusia untuk mencari ilmu. Dengan demikian upaya tersebut tidak lepas dengan pendidikan, dan tujuan pendidikan tidak akan tercapai secara optimal tanpa adanya manajemen atau pengelolaan pendidikan yang baik, yang selanjutnya dalam kegiatan manajemen pendidikan diperlukan adanya pemimpin yang memiliki kemampuan untuk menjadi seorang pemimpin.

Faktor yang paling penting dalam kegiatan menggerakkan orang lain untuk menjalankan kegiatan administrasi/manajemen adalah kepemimpinan (leadership). Sebab kepemimpinanlah yang menentukan arah dan tujuan,

1 Ahmad Hatta, Tafsir Quran Perkata, Jakarta: Maghfirah Pustaka, 2009, hal.6.

2 Muhammad Nasib ar-Rifa'i, Ringkasan Tafsir Ibnu Katsir Jilid I, Jakarta: Gema Insani Press, 1999, hal. 103-105. 
memberikan bimbingan, dan menciptakan iklim kerja yang mendukung pelaksanaan proses administrasi secara keseluruhan. Kesalahan dalam kepemimpinan dapat mengakibatkan gagalnya organisasi dalam menjalankan misinya. Oleh sebab itu, mengapa kepemimpinan dianggap sebagai inti dari pada manajemen. Manusia diciptakan oleh Allah SWT ke muka bumi ini, sebagai khalifah (pemimpin) di muka bumi ini, oleh sebab itu maka manusia tidak terlepas dari perannya sebagai pemimpin, kepemimpinan merupakan peran sentral dalam setiap upaya pembinaan. Peran kepemimpinan begitu menentukan dalam mencari sebab-sebab jatuh bangunnya suatu lembaga.

Peran utama dalam menjalankan pola manajemen sekolah terletak pada kepala sekolah dan seluruh komunitas sekolah, baik secara bersama-sama maupun individu. Kepala sekolah adalah orang yang bertanggung jawab untuk menjalankan roda organisasi sekolah. Menyikapi tentang peran, fungsi dan tanggungjawab kepala sekolah hendaknya memiliki komitmen yang tinggi atas pekerjaannya di samping profesional dan berdedikasi. Sebagai pemimpin di sekolah, kepala sekolah merupakan individu yang dituntut mampu melakukan transformasi kemampuannya melalui bimbingan, tuntunan dan pemberdayaan kepada seluruh warga sekolah demi mencapai tujuan sekolah yang optimal. ${ }^{3}$

Model kepemimpinan kepala sekolah merupakan harapan yang tinggi bagi peningkatan kualitas pendidikan, karena keberhasilan pendidikan di sekolah akan mempunyai pengaruh secara langsung terhadap hasil belajar siswa. Sehubungan dengan itu, kepala sekolah harus mampu melaksanakan peran dan fungsi supervisor kepada guru untuk mengembangkan profesi. Dalam kaitannya dengan peningkatan kompetensi guru, kepala sekolah tidak hanya sebagai manajer yang mengatur segala sesuatu tentang proses belajarmengajar, tetapi harus tampil sebagai instructional leader (pemimpin pengajaran) yang bertugas mengawasi jalannya kegiatan belajar-mengajar di sekolah yang dipimpinnya. ${ }^{4}$ Dalam dunia pendidikan, pemberdayaan merupakan cara yang sangat praktis dan produktif untuk mendapatkan hasil yang terbaik, dari kepala sekolah (manajer), para guru, dan para pegawai. Proses yang ditempuh untuk mendapatkan hasil terbaik dan produktif tersebut adalah dengan membagi tanggung jawab secara proporsional kepada para guru. Satu prinsip penting dalam pemberdayaan ini adalah melibatkan guru dalam proses pengambilan keputusan dan tanggung jawab.

Salah satu model kepemimpinan adalah kepemimpinan transformasional sebagaimana yang telah diterapkan oleh kepala sekolah SDN Kedaung Kaliangke 03 Pagi selama menjadi sekolah model. Kepemimpinan transformasional adalah kepemimpinan mampu mengubah energi sumber daya, baik manusia, instrumen, maupun situasi untuk mencapai tujuan. Kepemimpinan transformasional memiliki sifat-sifat: kharismatik, kekuatan 
membangkitkan inspirasi, kemahiran merangsang intelektual para bawahan secara aktif, bersifat tenggang rasa secara individu. Kepemimpinan transformasional memiliki ciri-ciri: Idealized influence, indvidualized consideration, inspirational motivation, intelektual simulation.

Penerapan gaya kepemimpinan transfomasional Kepala sekolah terlihat pada: kemampuan merumuskan visi, misi, dan program sekolah, menjadi agen perubahan, memiliki kharisma, memiliki empatik, merangsang intelektualitas dan menumbuhkan kreativitas, memberi kesempatan kepada semua unsur di sekolah. Penerapan kepemimpinan transformasional kepala sekolah membawa pengaruh kepada menyelenggarakan proses pembelajaran yang secara profesional. Tercipta budaya dan iklim sekolah yang kondusif, tercapainya prestasi belajar siswa yang tinggi.

Dalam upaya meningkatkan mutu pendidikan nasional, pemerintah khususnya melalui Depdiknas terus menerus berupaya melakukan berbagai perubahan dan pembaharuan sistem pendidikan kita. Salah satu upaya yang sudah dan sedang dilakukan, yaitu berkaitan dengan faktor guru. Lahirnya Undang-Undang No. 14 tahun 2005 tentang Guru dan Dosen dan Peraturan Pemerintah No. 19 Tahun 2005 tentang Standar Nasional Pendidikan, pada dasarnya merupakan kebijakan pemerintah yang didalamnya memuat usaha pemerintah untuk menata dan memperbaiki mutu guru di Indonesia.

Michael G. Fullan yang dikutip oleh Suyanto dan Djihad Hisyam mengemukakan bahwa: "educational change depends on what teachers do and think". Pendapat tersebut mengisyaratkan bahwa perubahan dan pembaharuan sistem pendidikan sangat bergantung pada "what teachers do and think" atau dengan kata lain bergantung pada penguasaan kompetensi guru. Menurut Moh.Uzer Usman profesionalitas guru ditunjukkan dalam tingkat kinerjanya yang tinggi di sekolah. Kinerja guru tersebut diwujudkan melalui kemampuannya mendidik, mengajar, dan melatih para peserta didik dalam proses pembelajaran dan mampu menghasilkan peserta didik (output) yang berkualitas. ${ }^{5}$

Menurut Sagala kinerja guru merupakan faktor yang menentukan keberhasilan pelaksanaan program-program pendidikan di sekolah. Karena itu kinerja guru merupakan elemen strategis yang perlu dikembangkan, sehingga guru sebagai tenaga pendidik memiliki kemampuan profesional dan mampu melahirkan proses pendidikan yang relevan dengan tuntutan situasi, kondisi, dan kebutuhan masyarakat pengguna lulusan. Sebaliknya kinerja guru yang rendah (tidak memenuhi standar kerja) akan berdampak negatif bagi proses pendidikan di sekolah. ${ }^{6}$ Hal ini ditegaskan oleh Jones dan kawan-kawan yang menyatakan bahwa guru yang kinerjanya kurang memuaskan tidak hanya gagal meningkatkan standar kinerjanya sendiri, tetapi juga berdampak pada kinerja orang-orang yang berhubungan dengan mereka seperti para staff lain, para

5 Moh. Uzer Usman, Menjadi Guru Profesional, Bandung: Remaja Rosdakarya, 2008, hal. 6 6 Syaiful Sagala, Supervisi Pembelajaran, Bandung: Alfa Beta, 2009, hal. 14 
siswa. Sebagaimana dikutip oleh Darmadi dari Jeff Jones dan Lord mengatakan bahwa kinerja guru yang rendah dapat memberikan dampak yang negatif pada reputasi dan peringkat sekolah, pencapaian dan kemajuan para murid. ${ }^{7}$

Jika kita amati lebih jauh tentang realita kompetensi guru saat ini agaknya masih beragam. Sudarwan Danim mengungkapkan bahwa salah satu ciri krisis pendidikan di Indonesia adalah guru belum mampu menunjukkan kinerja (work performance) yang memadai. Hal ini menunjukkan bahwa kinerja guru belum sepenuhnya ditopang oleh derajat penguasaan kompetensi yang memadai, oleh karena itu perlu adanya upaya yang komprehensif guna meningkatkan kompetensi guru. ${ }^{8}$

\section{B. METODE}

Penelitian ini merupakan penelitian lapangan ( Field study research) yang bermaksud mempelajari secara intensif tentang latar belakang keadaan sekarang dan interaksi sosial, individu, kelompok, lembaga dan masyarakat. Dalam hal ini adalah yang ada hubungan dengan lembaga pendidikan. ${ }^{9}$ Peneliti akan meneiliti pada SDN Kedaung Kaliangke 03 Pagi, Kelurahan Kedaung Kaliangke, Kecamatan Cengkareng, Jakarta Barat.

Jenis penelitian ini adalah penelitian kualitatif dengan metode deskriptif analitis, yaitu berusaha memaparkan secara sistematis materi-materi pembahasan yang berasal dari berbagai sumber untuk kemudian dianalisis dengan cermat guna memperoleh hasil sebagai kesimpulan. Dengan kata lain penelitian deskriptif mengambil masalah atau memusatkan perhatian pada masalah-masalah aktual sebagaimana adanya saat penelitian dilaksanakan. ${ }^{10}$

Penelitian ini mengkaji bentuk, aktifitas, karakteristik, perubahan, hubungan, kesamaan, dan perbedaan dengan fenomena lain. ${ }^{11}$ Sedangkan pendekatan yang digunakan dalam penelitian ini adalah pendekatan kualitatif. Pendekatan kualitatif merupakan salah satu pendekatan yang menggunakan paradigma pengetahuan berdasarkan pandangan konstruktivitik yaitu pengalaman individual, sosial, dan hostori yang dibangun dengan maksud mengembangkan sebuah teori. ${ }^{12}$

7 Jeff Jones \& Lord, S, Developing effective teacher performance, London: Paul Chapman Publishing, 2006, hal. 2

8 Sudarwan Danim, Inovasi Pendidikan: Dalam Upaya Meningkatkan Profesionalisme Tenaga Kependidikan. Bandung : Pustaka Setia, 2000, hal. 32

9 Husaini Usman dan Purnomo Setiyadi Akbar, Metodologi penelitian sosial, Jakarta: Bumi Aksara, 2000, hal. 5

10 Nana Sudjana Ibrahim, Penelitian Pendidikan, Bandung: Sinar Baru, 2000, hal. 64

11 Nana Syaid Sukmadinata, Metode penelitian pendidikan, Bandung: Remaja Rosyada, 2007, hal. 72

12 Emzir, Metodolodi penelitian kuantitatif dan kualitatif, Jakarta: Raja Grafindo Persada, 2008, hal, 28 
Alasan penggunaan metode penelitian kualitatif ini yaitu karena permasalahan bersifat holistik, kompleks, dinamis dan penuh makna sehingga tidak mungkin data pada situasi sosial tersebut dijaring dengan metode kuantitatif. Selain itu peneliti bermaksud memahami situasi situasi sosial secara mendalam, menemukan pola, hipotesis dan teori. ${ }^{13}$ Selain itu juga dikarenakan;

1) lebih mudah mengadakan penyesuaian dengan kenyataan yang berdimensi ganda.

2) lebih mudah menyajikan secara langsung hakikat hubungan antara peneliti dan subjek penelitian,

3) memiliki kepekaan dan daya penyesuaian diri dengan banyak pengaruh yang timbul dari pola-pola nilai yang dihadapi. ${ }^{14}$

Margono menambahkan bahwa dalam penelitian kualitatif ini analisis yang digunakan lebih bersifat deskriftif-analitik yang berarti interpretasi terhadap isi dibuat dan disusun secara sistemik/menyeluruh dan sistematis. ${ }^{15}$

\section{HASIL DAN PEMBAHASAN}

Dalam bahasa Arab, kepemimpinan sering diterjemahkan sebagai alRiyadah, al-imarah, al-qiyadah, atau al-zaamah. Kata-kata tersebut memiliki satu makna sehingga disebut sinonim atau muradif, sehingga kita bisa menggunakan salah satu dari keempat kata tersebut untuk menerjemahkan kata kepemimpinan. Sementara itu, untuk menyebut istilah kepemimpinan pendidikan, para ahli lebih memilih istilah qiyadah tarbawiyah. Secara singkat dapat dikatakan bahwa kepemimpinan adalah sifat yang harus dimiliki oleh perencana, pengorganisasi, pengarah, pemotivasi, dan pengendali untuk mempengaruhi orang-orang dan mekanisme kerja guna mencapai tujuan yang telah ditetapkan. ${ }^{16}$

Menurut Nawawi, kepemimpinan adalah proses menggerakkan, mempengaruhi, memberikan motivasi, dan mengarahkan orang-orang di dalam organisasi atau lembaga pendidikan tertentu untuk mencapai tujuan yang telah dirumuskan sebelumnya. Sedangkan salah satu Asosiasi supervisi dan pengembangan kurikulum di Amerika yakni Association for Supervision and Curiculum Development (ASCD), menyatakan bahwa kepemimpinan adalah tindakan atau tingkah laku di antara individu-individu dan kelompokkelompok yang menyebabkan mereka bergerak ke arah tercapainya tujuantujuan yang menambahkan penerimaan bersama bagi mereka. Orang yang menyebabkan mereka bergerak itulah yang disebut pemimpin, yakni seseorang

13 Sugiyono, Metode Penelitian Pendidikan; Pendekatan Kuantitatif, Kualitatif, dan RED, Bandung : Alfabeta, 2008, hal. 399

14 Moeloeng, J Lexy. Metodologi Penelitian Kualitatif, Bandung: Remaja Rosdakarya, 2009, hal. 4

15 Margono, Metodologi Penelitian Pendidikan, Jakarta: Rineka Cipta, 2002, hal. 36-37

16 Tri Supriyatno, Marno, Manajemen dan Kepemimpinan Kependidikan Islam, Bandung: Refika Aditma, 2008, hal. 30 
dengan wewenang kepemimpinannya mengarahkan bawahannya untuk mengerjakan sebagian dari pekerjaannya dalam mencapai tujuan ${ }^{17}$.

Yukl berpendapat bahwa sebagian besar definisi kepemimpinan mencerminkan asumsi bahwa kepemimpinan berkaitan dengan proses yang disengaja dari seseorang untuk membuat struktur, memfasilitasi aktivitas dan hubungan di dalam kelompok atau organisasi. ${ }^{18}$

Sedangkan Terry dalam Wahjosumidjo, menyatakan bahwa "Leadership is the activity of infuencing exercised to strive willingly for group objectives" (Kepemimpinan adalah kegiatan dalam mempengaruhi orang lain untuk bekerja keras dengan penuh kemauan untuk tujuan kelompok). Dari pendapat Terry dapat diartikan bahwa kepemimpinan itu adalah merupakan kemampuan untuk mempengaruhi dan menggerakkan orang lain untuk mencapai tujuan. ${ }^{19}$

Kepemimpinan transformasional adalah suatu keadaan dimana para pengikut dari seorang pemimpin transformasional merasa adanya kepercayaan, kekaguman, kesetiaan, dan hormat terhadap pemimpin tersebut, dan mereka termotivasi untuk melakukan lebih dari pada yang awalnya diharapkan mereka. Pemimpin tersebut mentransformasi dan memotivasi para pengikut dengan cara membuat mereka lebih sadar mengenai pentingnya hasil-hasil suatu pekerjaan, mendorong mereka untuk lebih mementingkan organisasi atau tim daripada kepentingan diri sendiri, dan mengaktifkan kebutuhan-kebutuhan mereka pada yang lebih tinggi. ${ }^{20}$

Menurut Bass dalam Robbins dan Judge kepemimpinan transformasional adalah pemimpin yang memberikan pertimbangan dan rangsangan intelektual yang diindividualkan dan memiliki kharisma. ${ }^{21}$ Untuk itu Bass telah merumuskan empat ciri atau kualitas pribadi dari pemimpin transformasional. Menurut Bass kepemimpinan transformasional ini sifatnya kontinum dan merupakan suatu tingkatan di atas kepemimpinan transaksional. Bass tidak sependapat dengan Burns yang mengatakan bahwa kepemimpinan transformasional merupakan kebalikan dari kepemimpian transaksional. Keempat dimensi tersebut dapat dilihat pada gambar berikut ini:

\section{Idealized} Influence

17 H. Malayu S.P. Hasibuan, Manajemen: Yasar, Pengertian, dan Masalah, Cet. VI, Jakarta: Bumi Aksara, 2007, hal. 43

18 Gary Yukl, dalam Organisasi, Jakar'

19 Wahjosum

Persada, 1994, hal. 25

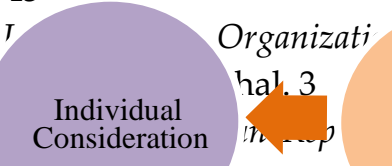
nahkan o Pemimpin

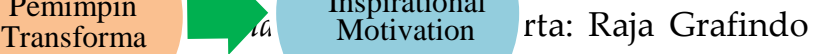
sional

20 Gary Yulk, Le. _ _l Organizatioı, , _mahkan oleı.

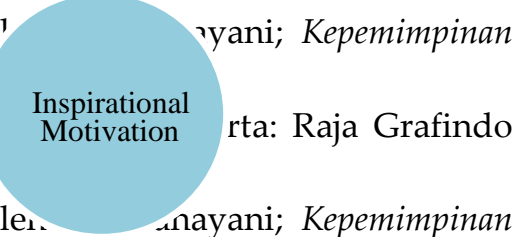
dalam Organisasi, Jakarta: Indeks, 2015, hal. 313

21 Stephen Robbins dan Timothy Judgr : smahkan oleh Hadaya Pujatmaka; Perilaku Organisasi, Buku 1, Edisi 12. Jakarta: Salemba $F$ 1. 387 
Untuk mempermudah penilaian, Avolio dan Bass memodifikasi keempat dimensi tersebut menjadi beberapa variabel yang lebih sederhana untuk digunakan sebagai penentu apakah seorang atasan mempunyai gaya kepemimpinan transformasional atau tidak. Variabel yang terkandung di dalamnya terrliha berbagai unsur-unsur yang bisa dipandang dari hal yaitu:

a) Idealized influence (pengaruh ideal), meliputi; dapa menjadi teladan yang baik bagi bawahan, mempunyai standar moral dan etika yang tinggi, menghargai bawahan/karyawan, memiliki kepercayaan penuh kepada bawahan saat mengerjakan tugasnya.

b) Inspirational motivation (motivasi inspirasi), meliputi: mempunyai waktu untuk berkomunikasi dengan karyawan dan dapat memberikan motivasi pada bawahanagar mengerjakan tugasnya dengan maksimal.

c) Intellectual stimulation (stimulasi intelektual) meliputi: dapat menumbuhkan kreativitas dan inovasi dari bawahan, mengikutsertakan bawahan dalam mencari solusi pada permasalahan di organisasi.

d) Individualized consideration (konsiderasi individu) meliputi: memiliki empati kepada bawahan, dapat berperan sebagai pelatih dan guru yang baik untuk bawahan dalam kegiatan pembelajaran, ikut mendengar masalah bawahan dan memberikan solusi terbaik dan mengutamakan keperluan bawahan.

Erik Ress mengemukakan bahwa ada 7 paradigma baru dalam kepemimpinan transformasional yang dapat ditinjau dari perspektif Al-Qur'an sebagai berikut:

1) Simplifikasi 
Keberhasilan dari kepemimpinan diawali dengan sebuah visi yang jelas, praktis dan dapat mengarahkan kemana organisasi tersebut akan melangkah, sebagaimana firman Allah Swt dalam Q.S. Ibrahim/14:4:

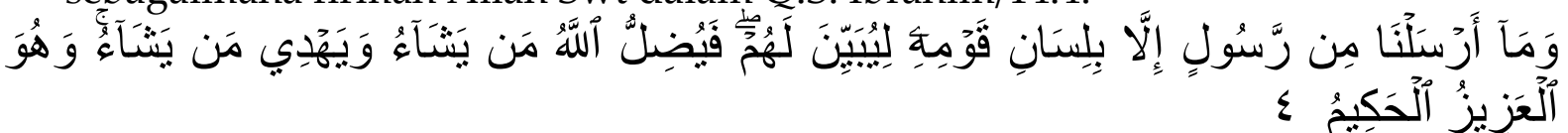

"Kami tidak mengutus seorang rasulpun, melainkan dengan bahasa kaumnya, supaya ia dapat memberi penjelasan dengan terang kepada mereka. Maka Allah menyesatkan siapa yang Dia kehendaki, dan memberi petunjuk kepada siapa yang Dia kehendaki. Dan Dialah Tuhan Yang Maha Kuasa lagi Maha Bijaksana." (Ibrahim/14: 4)

Ibnu Katsir dalam tafsirnya menjelaskan bahwa hal ini merupakan salah satu dari kelembutan Allah kepada makhluk-Nya, yaitu Dia mengutus kepada mereka rasul-rasul dari kalangan mereka sendiri yang berbahasa sama dengan mereka, agar mereka dapat memahami para rasul dan memahami risalah yang dibawa oleh para rasul itu. Sehubungan dengan hal ini Imam Ahmad mengatakan:

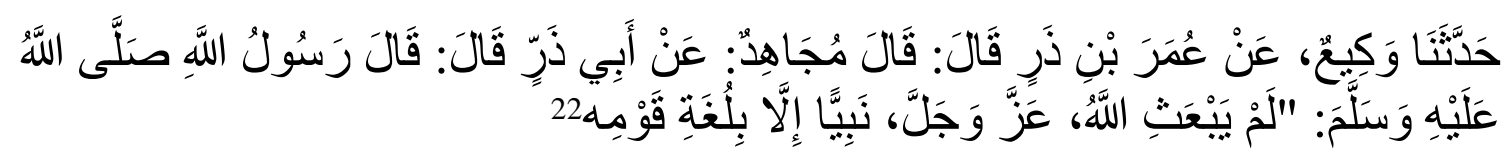

"Telah menceritakan kepada kami Waki', dari Umar ibnu Zar yang mengatakan bahwa Mujahid pernah meriwayatkan dari Abu Zar bahwa Rasulullah Saw. pernah bersabda: Tiadalah Allah Swt. mengutus seorang nabi melainkan dengan bahasa kaumnya". (HR. Ahmad)

Dari hadis di atas dapat dimengerti bahwa Allah Swt telah mengutus rasul dengan bahasa kaumnya, ${ }^{23}$ jika ditelisik lebih jauh yang dimaksud bahasa bukan hanya bahasa yang digunakan sehari-hari, Arab, Inggris, Indonesia dan lain sebagainya. Namun juga harus dapat memahamkan kaumnya dengan baik tentang apa yang disampaikan, secara kontekstual dan aktual. Begitu juga sebagai seorang pemimpin, pemimpin harus dapat menjelaskan visi, misi dan haluan organisasi yang dipimpinnya dengan baik dan jelas kepada seluruh individu yang terlibat dalam organisasi tersebut, sehingga tidak ada miss komunikasi dan kesalahfahaman satu sama lain. Ketidak jelasan dalam mengarahkan tim merupakan awal dari kegagalan dari sebuah kepemimpinan, dan tim akan bekerja dengan perspektif mereka masing-masing tanpa arah, sehingga akan sangat suit mencapai tujuan.

2) Motivasi

22 Ad-Dymasyqi, Tafsir Ibnu Katsir, diterjemahkan oleh M. Abdul Ghaffar, Vol. IV, 2004, Bogor: Pustaka Imam Syafi'i, hal. 520

23 Abdullah bin Muhammad bin Abdurrahmah, Tafsir Ibnu Katsir, Jakarta: Pustaka Imam Syafii, 2003, hal. 49. 
Kemampuan untuk mendapatkan komitemen dari setiap orang dalam tim merupakan hal yang penting, pada dasarnya setiap manusia memiliki naluri untuk selalu termotivasi, hadirnya pemimpin adalah untuk menjaga agar motivasi itu selalu ada dalam bentuk komitmen. Allah Swt berfirman:

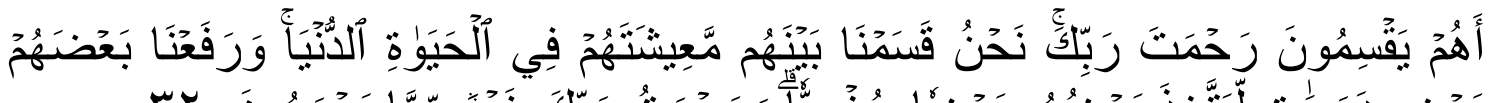

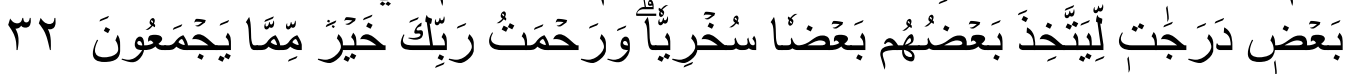

"Apakah mereka yang membagi-bagi rahmat Tuhanmu? Kami telah menentukan antara mereka penghidupan mereka dalam kehidupan dunia, dan Kami telah meninggikan sebagian mereka atas sebagian yang lain beberapa derajat, agar sebagian mereka dapat memanfaatkan yang lain. Dan rahmat Tuhanmu lebih baik dari apa yang mereka kumpulkan." (Az-Zukhruf/43: 32)

Ibnu Katsir dalam tafsirnya berpendapat bahwa makna ayat ialah agar sebagian dari mereka dapat memanfaatkan sebagian yang lain untuk melakukan pekerjaan-pekerjaan, karena yang lemah memerlukan yang kuat dan begitu pula sebaliknya. ${ }^{24}$ Demikianlah menurut pendapat Qatadah dan lain-lainnya. Qatadah dan Ad-Dahhak mengatakan bahwa makna yang dimaksud ialah agar sebagian dari mereka dapat menguasai sebagian yang lain.

Ayat ini mengindikasikan bahwa Allah Swt memberikan kelebihan bagi seseorang untuk dapat memanfaatkan yang lain, maksud dari memanfaatkan ini adalah dapat mengembangkan potensinya, menjaga motivasi untuk berkomitmen mencapai tujuan. Rasullullah Saw telah memberikan contoh dalam hal ini, salah satu cara beliau untuk memotivasi adalah dengan memberikan julukan-julukan indah bagi para sahabatnya. Abu Bakar diberi julukan ashShiddiq, Umar diberi julukan al-Faruq, Hamzah bin Abu Thalib dengan asadullah, dan lain sebagainya. ${ }^{25}$ Selain itu dalam perjalan perang Rasulullah Saw tidak pernah membiarkan timnya dalam keadaan depresi atau demotivasi, karena hal itu merupakan kewajiban seorang pemimpin.

\section{3) Fasilitasi}

Kepemimpinan transformasional harus mampu menjadi jembatan para individu yang ada di dalamnya untuk terus belajar dan mengembangkan dirinya, sebuah kepemimpinan harus peduli akan perkembangan setiap individu yang terlibat di dalamnya. Allah Swt berfirman:

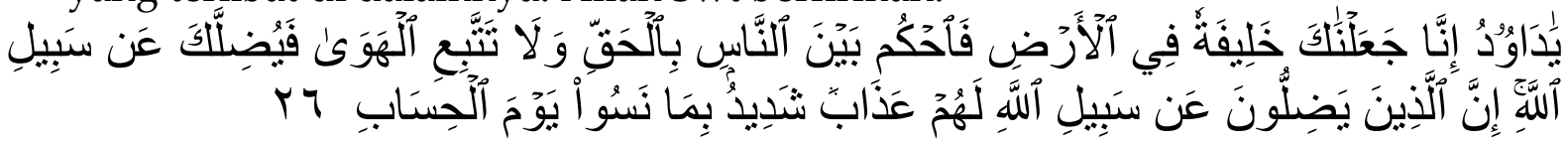

24 Ad-Dymasyqi, Tafsir Ibnu Katsir, diterjemahkan oleh M. Abdul Ghaffar, Vol. VII, 2004, Bogor: Pustaka Imam Syafi'i, hal. 280

${ }^{25}$ Muhammad Abdul Jawwad, Rahasia Sukses Manajemen Rasulullah, Surakarta: Ziyad Visi Media, 2009, hal. 23. 
"Hai Daud, sesungguhnya kami menjadikan kamu khalifah (penguasa) di muka bumi, maka berilah keputusan (perkara) diantara manusia dengana dil dan janganlah kamu mengikuti hawa nafsu, karena ia akan menyesatkan kamu dari jalan Allah" (Shaad/38: 26)

Ibnu Katsir dalam tafsirnya menjelaskan bahwa ayat ini merupakan perintah dari Allah Swt. kepada para penguasa agar mereka memutuskan perkara di antara manusia dengan kebenaran yang diturunkan dari sisi-Nya, dan janganlah mereka menyimpang darinya, yang berakibat mereka akan sesat dari jalan Allah. Allah Swt. telah mengancam orang-orang yang sesat dari jalan-Nya dan yang melupakan hari perhitungan, yaitu dengan ancaman yang tegas dan azab yang keras. ${ }^{26}$

Ayat ini dengan tegas menyatakan bahwa sebuah kepemimpinan harus didasari dengan keadilan, keterjaminan dan kenyamanan bagi rakyat atau pengikutnya, salah satu manifestasi dari hal tersebut adalah para pengikut terfasilitasi untuk mengembangkan dirinya sebagai rakyat atau pengikut dari pemimimpin yang tranformasional.

\section{4) Inovasi}

Setiap organisasi tidak boleh takut akan perubahan, justru harus membangun budaya untuk selalu malakukan perubahan, dalam kepemimpinan transformasional, pilihannya hanya dua inovasi atau mati. Allah Swt Berfirman:

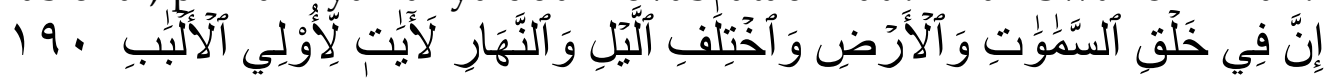

"Sesungguhnya dalam penciptaan langit dan bumi, dan pergantian malam dan siang terdapat tanda-tanda (kebesaran Allah) bagi orang berakal" (Ali Imran/3: 190)

Ibnu Kasir dalam tafsirnya menjelaskan bahwa teks ayat tersebut memberi isyarat pada fakta-fakta kosmis yang menunjuk pada keagungan Pencipta. Ayat ini merupakan sebuah stimulus dari Allah Swt bagi segenap hambanya untuk selalu berfikir hal-hal baru yang inovatif dan kreatif, sebagaimana orang-orang yang berakal. ${ }^{27} \mathrm{Hal}$ tersebut juga harus dimiliki oleh pemimpin transformasional, harus mampu merangsang rasa ingin tau timnya untuk berpikir kreatif dan inovatif.

\section{5) Mobilitas}

Kepemimpinan transformasional harus mampu mendistribusi kan tanggungjawab dengan jelas dan cekatan kepada setiap orang yang terlibat di dalamnya. Allah Swt berfirman:

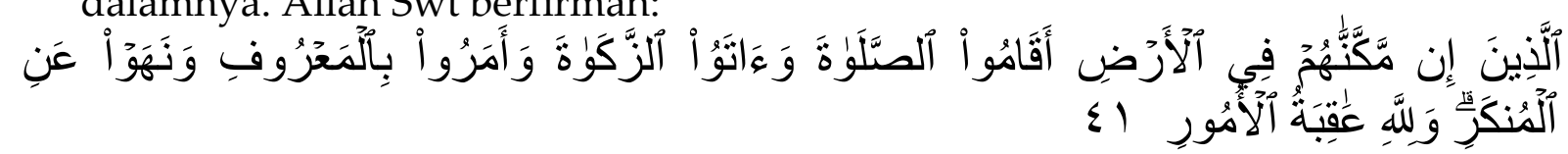

26 Ad-Dymasyqi, Tafsir Ibnu Katsir, diterjemahkan oleh M. Abdul Ghaffar, Vol. VII, 2004, Bogor: Pustaka Imam Syafi'i, hal. 63

${ }^{27}$ Ad-Dymasyqi, Tafsir Ibnu Katsir, diterjemahkan oleh M. Abdul Ghaffar, Vol. II, 2004, Bogor: Pustaka Imam Syafi'i, hal. 243 
"(yaitu) orang-orang yang jika Kami teguhkan kedudukan mereka di muka bumi niscaya mereka mendirikan sembahyang, menunaikan zakat, menyuruh berbuat yang ma'ruf dan mencegah dari perbuatan yang mungkar;dan kepada Allah-lah kembali segala urusan." (Al-Hajj/22: 41)

Sebagaimana maksud dari mobilitas adalah upaya untuk melengkapi dan memperkuat setiap orang yang terlibat dalam sebuah tim, maka ayat ini menjadi semangat bahwa setiap individu dari sebuah tim yang utuh, haruslah saling melengkapi satu sama lain dan saling mengingatkan. Menyeru kepada kebajikan dan sebaliknya. Pengerahan semua sumber daya yang ada untuk melengkapi dan memperkuat setiap orang yang terlibat di dalamnya dalam mencapai visi dan tujuan. Pemimpin transformasional akan selalu mengupayakan pengikut yang penuh dengan tanggung jawab.

M. Quraish Shihab dalam tafsirnya menjelaskan mengenai ayat ini maksudnya adalah Orang-orang Mukmin yang telah Kami janjikan untuk mendapatkan pertolongan Kami adalah mereka yang apabila kekuasaan mereka Kami kokohkan di bumi, akan menjaga hubungan mereka dengan Allah dan manusia. ${ }^{28}$ Mereka kemudian mengerjakan salat dengan cara yang benar, membayar zakat dan menyalurkannya kepada yang berhak, menyuruh berbuat baik dan melarang berbuat jelek. Hanya Allah yang berhak menentukan akhir dari semua perkara, dan membuat hina siapa saja yang dikehendaki-Nya.

Abu Aliyah berkata: mereka para sahabat. Atthiyah al-Aufi berkata tentang ayat ini sebagaimana firman Allah Swt yang artinya "...bahwa Dia sungguh-sungguh akan menjadikan mereka berkuasa (memimpin) di bumi.." (QS. AnNuur/24: 55) $)^{29}$

6) Siap Siaga

Siap siaga merupakan kemampuan untuk selalu siap dalam menyambut hal-hal baru yang berkaitan dengan tim dan tujuan dari organisasi. Allah Swt berfirman;

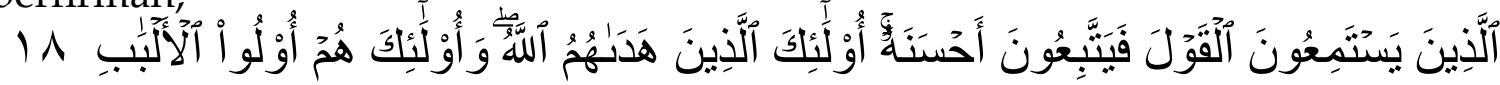
"Yang mendengarkan perkataan lalu mengikuti apa yang paling baik diantaranya mereka itulah orang-orang yang diberi Allah Swt pentunjuk dan mereka itulah orang-orang yang mempunyai akal" (Az-Zumar/39: 18)

Ibnu Katsir dalam tafsirnya menjelaskan bahwa Abdur Rahman ibnu Zaid ibnu Aslam telah meriwayatkan dari ayahnya sehubungan dengan makna firmanNya: Dan orang-orang yang menjauhi tagut (yaitu) tidak menyembahnya. (Az-Zumar: 17) Ayat ini diturunkan berkenaan dengan Zaid ibnu Amr ibnu Nufail r.a, Abu

28 M. Quraish Shihab, Tafsir al-Misbah; Pesan, Kesan, dan Keserasian Al-Qur'an, Vol. IX, Jakarta: Lentera Hati, 2005, hal. 154

${ }^{29}$ Abdullah bin Muhammad bin Abdurrahmah, Tafsir Ibnu Katsir, Jakarta: Pustaka Imam Syafii, 2003, hal. 177. 
Zar r.a, dan Salman Al-Farisi r.a. Tetapi yang benar ayat ini mencakup mereka dan orang-orang selain mereka dari kalangan orang-orang yang menjauhi penyembahan berhala dan selalu taat menyembah Tuhan Yang Maha Pemurah. Maka merekalah orang-orang yang mendapat berita gembira dalam kehidupan dunia dan akhiratnya. ${ }^{30}$

Ayat ini merupakan suatu anjuran bagi seorang pemimpin harus siap siaga dalam segala hal, mengambil contoh kebaikan dari pengalaman, dan merespon cepat dalam masalah yang dihadapi dalam organisasi yang dipimpinya.

7) Tekad

Tekad adalah kemauan yang tinggi untuk mencapai tujuan akhir, serta menyelesaikan sesuatu dengan baik dan tuntas. Allah Swt berfirman;

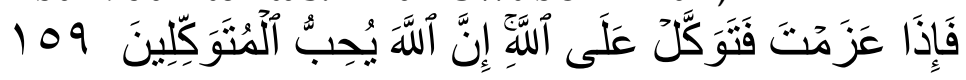

"Kemudian apabila kamu telah membulatkan tekad, maka bertakkallah kepada Allah, Sesungguhnya Allah itu menyukai orang-orang yang bertawakkal." (Al-Imran/3: 159)

Ibnu Katsir dalam tafsirnya menjelaskan bahwa apabila engkau bermusyawarah dengan mereka dalam urusan itu, dan kamu telah membulatkan tekadmu, hendaklah kamu bertawakal kepada Allah dalam urusan itu. Dari sini dapat kita ketahui bahwa kepemimpinan transfromasional haruslah sampai kepada tujuannya, mencapai target yang diinginkan. Oleh karena itu dalam memulainya haruslah dengan tekad yang sungguh-sungguh akan menyelesaikan tanggungjawab tersbut secara totalitas, sebagaimana makna tersirat dan tersurat ayat diatas. ${ }^{31}$

Dari penjelasan prinsip-prinsip di atas, dapat kita simpulkan bahwa AlQur'an dapat menjadi panduan manusia untuk menjadi pemimpin yang tranformasional, hal ini menjawab bahwa Al-Qur'an adalah kitab suci yang penggunaannya tak lekang oleh waktu dan dapat dijadikan rujuakan dalam segala aspek kehidupan.

Selain itu, ayat-ayat kepemimpinan dalam Al-Qur'an ini telah diamalkan oleh Rasulullah Saw, para sahabat, tabiin, ulama hingga umat dewasa ini, dan keberhasilan kepemimpinan mereka dicatat dengan tinta emas dalam lembar sejarah peradaban manusia. Tidak hanya sebagai pemimpin agama, tetapi juga sebagai penyelenggara negara, sebagaimana beliau mempimpin Madinah yang majemuk dan beragam, dan menyatukan masyarakat Madinah dengan Piagam

30 Ad-Dymasyqi, Tafsir Ibnu Katsir, diterjemahkan oleh M. Abdul Ghaffar, Vol. VII, 2004, Bogor: Pustaka Imam Syafi'i, hal. 97

31 Ad-Dymasyqi, Tafsir Ibnu Katsir, diterjemahkan oleh M. Abdul Ghaffar, Vol. II, 2004, Bogor: Pustaka Imam Syafi'i, hal. 172 
Madinah. ${ }^{32}$ Hal ini kembali menguatkan Al-Qur'an sebagai kitab kepemimpinan yang transformasional.

Dalam prakatik kepemimpinan transformasional yang dijalankan oleh kepala SDN Kedaung kaliangke 01 Pagi selain sesuai dengan komponen kepemimpinan transformasional yang dikemukakan oleh Bernard M. Bass dan James Burns, yaitu Idealized Influence, Inspirational Motivation, Intellectual stimulation, dan Individualized consideration, kepala sekolah melakukan internalisasi nilai-nilai karakter yang dibudayakan dalam kegitan sehari-hari. Sehingga menimbulkan satu komponen baru yaitu Initiative of Culture.

Dari hasil penelitian proses internalisasi nilai-nilai karakter dalam meningkatkan kepribadian guru melalui pembinaan kepala sekolah ini meliputi; Pertama, pembinaan dan pembiasaan dengan kegiatan tilawah al-qur'an setiap hari jum'at, solat duha bersama diwaktu pagi yang dipimpin oleh koordinator keagamaan. Kedua, reward (hadiah dan dukungan bagi guru yang berprestasi) and Punisment (bagi guru yang melanggar peraturan). Ketiga, aturan-aturan sekolah/norma-norma sekolah berupa tata tertib atau SOP sekolah. Keempat, Persuasive (ajakan) melalui kegiatan solat duha dan kajian bersama, baksos, serta peringatan hari besar islam. Kelima penciptaan suasana yang islami/religius seperti pembacaan tilawatil qur'an setiap pagi, sholat dhuha berjemaah, sholat dhuhur berjemaah, serta makan pagi bersama, serta membudayakan mengucapkan salam ketika bertemu dan berjabat tangan sesama jenisnya.

Selanjutnya dalam membudayakan nilai-nilai karakter agar bisa berjalan dan terinternalisasi dengan baik maka menggunakan teori prof Muhaimin yaitu power strategi, Persuasive dan Normative re-educative ${ }^{33}$.

1. Power Strategi merupakan strategi pembudayaan nilai-nilai karakter dengan cara menggunakan kekuatan atau kekuasaan melalui people's power yang ada di lembaga tersebut.

2. Persuasive strategi yang dijalankan melalui pembentukan opini dan pandangan masyarakat atau warga sekolah.

3. Normative Re-educative, norma adalah aturan yang berlaku dimasyarakat. Norma termasyarakatkan melalui educative. Normative digandengkan dengan re-educative (Pendidikan Ulang) untuk menanamkan dan mengganti paradigm berfikir masyarakat sekolah yang lama dengan yang baru.

Jika dikaitkan dengan teori lichona proses pertama yang ditanamkan adalah dengan dengan pengunaan power yaitu reward and punishment, yaitu di SDN Kedaung Kaliangke 01 Pagi jika berprestasi dan melaksanakan tugas dengan baik dan tepat waktu maka di beri reward atau apresiasi namun jika

${ }^{32}$ Ikhwan Fauzi, dkk. Ensiklopedia Nabi Muhammad Sebagai Pemimpin, Jakarta: Lentera Abadi, 2013, hal. 25.

33 Muhaimin, Model Pengembangan Kurikulum dan Pembelajaran dalam Pendidikan Islam Kontemporer di Sekolah dan Perguruan Tinggi, Malang: UIN Maliki Press,2016, hal. 84 
melanggar ketentuan atau aturan-aturan yang telah disepakati bersama termasuk kedisiplinan dan kode etik guru, maka guru tersebut akan di berikan punishment (teguran/hukuman) sesuai dengan pelanggaran yang dilakukannya dan yang termasuk dalam hal ini seperti kedisiplinan (kedatangan dan kepulangan) dan berseragam, mengikuti ta'lim dan kegiatan keagamaan lainya.

Kedua adalah Persuasive strategi yang dijalankan melalui pembentukan opini dan pandangan masyarakat atau warga sekolah. Meliputi program pembinaan dan pembiasaan rutin mengajak semua guru dan karyawan tilawah qur'an setiap pagi, Kuliah dhuha, mabit, jaslah ruhiyah, halaqoh, Taklim, parenting, paguyuban, menjenguk teman yang sakit dan menghadiri undangan, serta sholat fardu berjemaah dan penciptaan suasana islami (religious) dengan kegiatan tilawah dipagi hari, membudaykan 3S (salam, senyum dan sapa), dan berjabat tangan, sholat dhuha, dhuhur dan ashar berjemaah, serta makan bersama dengan menggunakan adab makan. Selanjutnya semua pembiasaan tersebut tidak hanya berlaku di lingkungan sekolah saja melainkan diterapkan dalam kehidupan sehari-hari di lingkungan masyarakat.

Ketiga Normative re-educative, aturan-aturan yang dibuat oleh kepala sekolah dan lembaga dimana aturan-aturan tersebut telah disepaki bersama untuk dijalankan dan tentunya disana ada konsekwensi logis bagi guru atau karyawan yang melanggar dengan beberapa tahapan mulai dari teguran, pembinaan dan bimbingan sampai pada pemecatan. Dan proses dari normative re educative ini sangat panjang mulai dari rekrutment guru (sesuai dengan standart kualifikasi), tes tulis, interview, psikotest, magang dan diterima. Dan pembinaan serta bimbingan tersebut terus dilakukan selama guru tersebut berada dilingkungan sekolah atau bahkan keluar dari sekolah. Semua hal yang dilakukan diatas tersebut juga merupakan bentuk dari moral action.

\section{KESIMPULAN}

Berdasarkan hasil penelitian di atas, maka dapat disimpulkan:

1. Model kepemimpinan kepala SDN Kedaung Kaliangke 03 Pagi yang diterapakan adalah kepemimpinan transformasional dengan melakukan internalisasi nilai-nilai karakter untuk menciptakan budaya relegius sekolah sebagai upaya peningkatan kompetensi kepribadian guru.

2. Praktik kepemimpinan transformasional yang diterapkan oleh kepala SDN Kedaung Kaliangke 03 Pagi mengalami pengembangan komponen kepemimpinan transformasional dari 4 komponen sebagaimana teori Bernad Bass dan James Mc. Burns yang dikenal dengan "Four I's" menjadi 5 komponen atau disebut "Five I's" diantaranya: idealized influence, inspirational motivation, intellectual stimulation, individualized consideration, dan Initiative of Culture. 
Implikasi dari internalisasi nilai karakter yang telah diterapkan oleh kepemimpinan transformasional kepala sekolah terhadap peningkatan kompetensi kepribadian guru yaitu adanya peningkatan;

1. Kepribadian yang mantap dan stabil dengan indikator; guru taat pada norma hukum,sosial dan agama, bangga menjadi guru dan bersih aqidahnya

2. Meningkatnya kerpibadian yang dewasa dengan indikator; kemandirian, sabar tidak emosi, serta memiliki etos kerja.

3. Adanya peningkatan kerpibadian yang arif yaitu dengan indikator; pola berfikir dan bertindak sesuai dengan norma agama dan budaya setempat.

4. Kepribadian yang berwibawa dengan indikator; gaya dan prilaku para guru yang terbuka ketika diajak bicara dan berprilaku sopan serta tidak melakukan hal-hal yang menghilangkan martabat guru.

5. Adanya peningkatan keteladan dengan inidikator; para guru tidak kasar dalam bersikap, baik dari segi gaya bicaranya tidak sombong, dan penampilannya juga rapi dan menarik dan terbiasa kerja keras.

6. Meningkatnya kedisiplinan para guru. indikatornya dari dokumen absensi $99 \%$ aktif.

7. Kepribadian yang memiliki akhlak mulia indikatornya; tidak adanya guru yang bertindak melanggar norma-norma agama, bersikap jujur, ikhlas dan suka menolong. 


\section{DAFTAR PUSTAKA}

Adam. Perilaku Organisasi, Bandung: Sinar Baru Algesindo, 2002.

Adrianto, Nico. Good Government : Transparansi dan Akuntabilitas Publik Melalui eGovernment, Palangkaraya: Bayu Media, 2007.

Almigo, Nusep. "Hubungan Antara Kepuasan Kerja dengan Produktivitas Kerja Karyawan”, Jurnal Psyche, No. 1/I, 26 Agustus 2004, hal 50-60.

Alwi, Syafaruddin. Manajemen Sumber Daya Manusia-Strategi Keunggulan Kompetitif, Edisi Pertama. Yogyakarta: BPFE, 2005.

Abdurrahman, Abdullah bin Muhammad bin Abdurrahmah, Tafsir Ibnu Katsir, Jakarta: Pustaka Imam Syafii, 2003.

Ad-Dymasyqi, Tafsir Ibnu Katsir, diterjemahkan oleh M. Abdul Ghaffar, Vol. IV, Bogor: Pustaka Imam Syafi'i, 2004.

Danim, Sudarwan. Inovasi Pendidikan: Dalam Upaya Meningkatkan Profesionalisme Tenaga Kependidikan. Bandung : Pustaka Setia, 2000.

Emzir, Metodolodi penelitian kuantitatif dan kualitatif, Jakarta: Raja Grafindo Persada, 2008.

Fauzi, Ikhwan Fauzi, dkk. Ensiklopedia Nabi Muhammad Sebagai Pemimpin, Jakarta: Lentera Abadi, 2013.

Hasibuan, Malayu S.P. Manajemen: Dasar, Pengertian, dan Masalah, Cet. VI, Jakarta: Bumi Aksara, 2007.

Hatta, Ahmad. Tafsir Quran Perkata, Jakarta: Maghfirah Pustaka, 2000.

Ibrahim, Nana Sudjana Ibrahim, Penelitian Pendidikan, Bandung: Sinar Baru, 2000.

Margono, Metodologi Penelitian Pendidikan, Jakarta: Rineka Cipta, 2002.

Moeloeng, J Lexy. Metodologi Penelitian Kualitatif, Bandung: Remaja Rosdakarya, 2009.

Muhaimin, Model Pengembangan Kurikulum dan Pembelajaran dalam Pendidikan Islam Kontemporer di Sekolah dan Perguruan Tinggi, Malang: UIN Maliki Press,2016.

Mulyasa, E. Menjadi Kepala Sekolah Profesional, Bandung: Remaja Rosdakarya, 2006.

Rifa'i , Muhammad Nasib, Ringkasan Tafsir Ibnu Katsir Jilid I, Jakarta: Gema Insani Press, 1999.

Sagala, Syaiful. Supervisi Pembelajaran, Bandung: Alfa Beta, 2009.

Shihab, M. Quraish Shihab, Tafsir al-Misbah; Pesan, Kesan, dan Keserasian Al-Qur'an, Vol. IX, Jakarta: Lentera Hati, 2005.

Stephen Robbins, Stephen dan Timothy Judge, diterjemahkan oleh Hadaya Pujatmaka; Perilaku Organisasi, Buku 1, Edisi 12. Jakarta: Salemba Empat, 2008. Sugiyono, Metode Penelitian Pendidikan; Pendekatan Kuantitatif, Kualitatif, dan RED, Bandung: Alfabeta, 2008.

Sukmadinata, Nana Syaid Sukmadinata, Metode penelitian pendidikan, Bandung: Remaja Rosyada, 2007.

Tri Supriyatno, Marno, Manajemen dan Kepemimpinan Kependidikan Islam, Bandung: Refika Aditma, 2008. 
ANDRAGOGI:

JURNAL PENDIDIKAN ISLAM, VOL. 1, NO. 1 TAHUN 2019

MAGISTER MANAJEMEN PENDIDIKAN ISLAM INSTITUT PTIQ JAKARTA

Usman, Moh. Uzer Usman, Menjadi Guru Profesional, Bandung: Remaja Rosdakarya, 2008

Wahjosumidjo, Kepemimpinan Kepala Sekolah dan Permasalahannya, Jakarta: Raja Grafindo Persada, 1994.

Yukl, Gary. Leadership In Organization, diterjemahkan oleh Ati Cahayani; Kepemimpinan dalam Organisasi, Jakarta: Indeks, 2015. 